\title{
Comparative lactic acid bacteria (LAB) profiles during dadih fermentation with spontaneous and back-slopping methods, as identified by terminal- restriction fragment length polymorphism (T-RFLP)
}

\author{
Chandra Utami Wirawati ${ }^{1, *}$, Mirnawati Bachrum Sudarwanto ${ }^{2}$, Denny Widaya Lukman ${ }^{2}$, letje Wientarsi ${ }^{3}$,Eko Agus \\ Srihanto ${ }^{4}$ \\ ${ }^{1}$ Food Technology Department, Politeknik Negeri Lampung, Soekarno Hatta Rajabasa 10, Bandar Lampung 35141, Indonesia \\ ${ }^{2}$ Department of Animal Diseases and Veterinary Public Health, Faculty of Veterinary Medicine, Bogor Agricultural University, Raya Dramaga \\ Bogor 16680 West Java, Indonesia \\ ${ }^{3}$ Departement of Veterinary Clinic Reproduction and Pathology Faculty of Veterinary Medicine, Bogor Agricultural University, Raya \\ Dramaga Bogor 16680 West Java, Indonesia \\ ${ }^{4}$ Lampung Veterinary Office, General Directorate Animal Husbandry and Healthiness, Agricultural Ministry Republic of Indonesia \\ ${ }^{*}$ Corresponding author: cutami@polinela.ac.id
}

SUBMITTED 9 November 2020 REVISED 15 March 2021 ACCEPTED 2 June 2021

\begin{abstract}
The diversity of lactic acid bacteria (LAB) present during the manufacture of traditional fermented buffalo milk from West Sumatra, known as dadih, was studied via a culture-independent approach using terminal-restriction fragment length polymorphism (T-RFLP) to compare the dynamic diversity in back-slopping and spontaneous fermentation methods. Total LAB and $\mathrm{pH}$ were measured in freshly prepared buffalo milk and in dadih fermented for 24 and 48 hours. The results indicated significant differences between the fermentation methods, with higher total LAB, and greater phylotype richness and relative abundance being identified in the back-slopping method. Terminal fragment lengths (TRFs) of 68 and $310 \mathrm{bp}$ were common to both techniques, similar to those of Lactobacillus fermentum, Fructobacillus pseudoficulneus, Leuconostoc citreum, Leuconostoc kimchii, and Leuconostoc sp. The changes in phylotype number (species number) and relative abundances of LAB communities identified are expected to produce data needed to formulate the best fermentation process for dadih manufacturing. A 24-hour back-slopping fermentation method is recommended, as fermentation time of longer than 24 hours reduced viable LAB significantly. Our results also indicated that the T-RFLP technique is not only clearly sensitive enough and adequate for segregating LAB diversity in both fermentation methods, but that it also provides good information regarding the structure of microbial communities and their composition change during the fermentation process.
\end{abstract}

KEYWORDS Dadih; lactic acid bacteria (LAB); dynamic diversity; T-RFLP

\section{Introduction}

Dadih is a traditional food product made from fermented buffalo milk produced in West Sumatera, and is one element of Indonesia's dietary richness. This product, made from buffalo milk fermented in bamboo tubes for 48 hours, has been consumed by Minangkabau tribes for many years. The manufacturing process requires the introduction of a complex LAB community and is also influenced by the composition and diversity of each LAB species involved. Over recent decades, numerous researchers have isolated and explored the influence of LAB in dadih, however reports about diversity during fermentation are still limited. Previous studies have shown that Enterococcus sp., Lactobacillus sp., Leuconostoc sp., Lactococcus sp. and Pediococcus sp. are the most commonly found genera in dadih (Mustopa and Fatimah 2014; Wirawati et al.
2019).

The indigenous LAB in fermented milk plays a significant role in the formation of flavour and texture, and in quality preservation. They also possess functional characteristics instrumental in generating bioactive components (Zhang et al. 2016). However, initial LAB populations in dadih production have been ignored, despite their potential influence on the quality and benefits of dadih. These features are also determined by changes in species type and abundance which further impact on product safety (Dervisoglu and Aydemir 2007). Previous studies have shown a relative abundance range of $8.5 \times 10^{9}$ to $1.0 \times 10^{9} \mathrm{log}$ $\mathrm{cfu} / \mathrm{mL}$ (Syukur et al. 2014), alongside varied LAB species in dadih obtained from various regions.

Recently, a study into the characterization of microbial consortia in an ecosystem was accomplished using culture- 
independent techniques, rather than the culture-dependent approach used in classical microbiology studies that produces incomplete identification and generates a narrow range of comprehensive information (Nduko et al. 2017). This conventional technique is time consuming and expensive since numerous limitations are faced during its application in the analysis of uncultured bacteria. This has been reported as a limitation in culture-dependent conditions, and this emphasizes the importance of exploring microbial dynamics and diversity through a culture-independent approach (Ercolini 2013).

Terminal-restriction fragment length polymorphism (T-RFLP) is a rapid, robust, inexpensive and simple tool for microbial community profiling (Prakash et al. 2014), combining selective PCR amplification of target genes with restriction of enzyme digestion, high-resolution electrophoresis and fluorescent detection. Also, these data are collectively added to single-strain characterization in order to enable the description and comparison of complex microbial communities which comprise large numbers of TRFs (around 60-80) (Rademaker et al. 2005). This is a popular high-throughput fingerprinting technique used to monitor changes in structure and composition, following variations in the 16 S rRNA gene (Schütte et al. 2008). This present study involves a molecular approach in which the T-RFLP technique is specifically used to analyse LAB communities in dadih obtained through two different fermentation processes.

\section{Materials and Methods}

\subsection{Material preparation}

Samples of dadih made by spontaneous and back-slopping fermentation methods were taken from two different locations in West Sumatra: Gadut, Limapuluh Kota and Kamang Agam, respectively. The obtained fresh buffalo milk and the dadih samples after $24 \mathrm{~h}$ and $48 \mathrm{~h}$ fermentation were evaluated for several parameters including $\mathrm{pH}$ (Hanna HI8424) and total LAB. Samples of $10 \mathrm{~g}$ were aseptically measured in a sterile tube and transferred to the laboratory under cool conditions $\left(4{ }^{\circ} \mathrm{C}\right)$ for further analysis.

\subsection{Microbial analysis (total LAB)}

One gram of each dadih sample was mixed with $45 \mathrm{~mL}$ of sterile $\mathrm{NaCl} 0.85 \%$, followed by the 7 to 8 times dilution (107-108). This was then inoculated onto De Man Rogosa Sharpe agar (Merck, German) containing 0.5\% $\mathrm{CaCO}_{3}$ medium and using a double-layer technique, and incubated at $37^{\circ} \mathrm{C}$ for $48 \mathrm{~h}$. The number of LAB colonies present was determined from the appearance of clear zones around them and expressed as colony-forming unit (cfu) per gram sample.

\subsection{DNA extraction and amplification}

DNA was extract from $0.5 \mathrm{~g}$ dadih samples using the Milk DNA preservation and isolation Kit (Norgen
Biotek) (Lackey et al. 2017) as per manufacturer's instructions. The LAB specific region in the 16S rRNA gene was amplified using the procedure conducted by Jernberg et al. (2005). Reaction mixture amounts of $50 \mathrm{~mL}$, consisting of primer forward $7 \mathrm{f}$ labelled with FAM (5'-6-FAM-AGAGTTTGATC/TA/CTGGCTCAG3'), non-labelled reverse primer SG-Lab-0.677 (5'CACCGCTACACATGGAG-3'), My Taq HS Red Mix (Geneaid) reagent and DNA template, were used. The amplification process was performed in an Applied Biosystems VerityTM. 96 well PCR, using an initial heat of $95^{\circ} \mathrm{C}$ for a denaturation step of $5 \mathrm{~min}$, followed by 30 cycles of $95^{\circ} \mathrm{C}$ denaturation for $40 \mathrm{~s}$, annealing at $55^{\circ} \mathrm{C}$ for $40 \mathrm{~s}$, extension at $72{ }^{\circ} \mathrm{C}$ for $1 \mathrm{~min}$, and, finally, last extension at 72 ${ }^{\circ} \mathrm{C}$ for $7 \mathrm{~min}$. The PCR product was confirmed with $0.8 \%$ agarose gel, and visualized using Gel Documentation System (Atto Corporation). Amplicon purification was conducted by GenepHlowTM Gel PCR Kit (Geneaid), as per manufacturer's instructions.

\section{4. $P C R$ product digestion}

Purified PCR products were digested by two individual restriction enzymes, HaeIII and DdeI (Geneaid) (Wanangkarn et al. 2014; Jannah et al. 2016). The samples were incubated at $37^{\circ} \mathrm{C}$ for $24 \mathrm{~h}$, and enzyme inactivation was completed at $80{ }^{\circ} \mathrm{C}$ for $20 \mathrm{~min}$, followed by immediate cooling in an ice bath, as stated in the manufacturer's instructions. The digested restriction products were then subjected to ethanol precipitation and dried and then sent to the Fragment Analysis $1^{\text {st }}$ Base (http://ww w.base-asia.com/fragment_analisys/) to generate sample TRFs. In addition, TRF lengths were determined by comparing with size standards (GeneScan-500 ROX; Applied Biosystems), using Peak ScannerTM software v2.0 (Applied Biosystems).

\subsection{Data analysis}

During dadih production, dynamic changes in LAB were measured in terms of numbers of phylotypes and labelled terminal fragments (TRF) with different lengths present in fresh and fermented milk ( 24 and $48 \mathrm{~h}$ ) obtained using both methods. The fluorescence signal was then distinguished from noise by setting a threshold. Peaks over 50 fluorescent units (TU) were used and T-RFs of $<50$ bp and $>$ 900 bp were precluded from analysis to avoid detection of primers and concerns over size determination. Each TRF was assumed as one phylotype (also as one species) (Moeseneder et al. 1999), with richness (S) being the total peaks identified in each sample digestion. The results obtained in the form of decimal fractions were rounded to the nearest TRF number, and those with similar length were assumed to represent one phylotype. These also represented changes in LAB diversity at each stage in dadih production (fresh milk, 24 and 48 h fermentation) using both methods (Efriwati et al. 2013).

Phylotype identification required T-RFLP In silico PCR and Restriction (ISPAR) program analysis from Microbial Community Analysis (MiCA) III, using the Ribo- 
somal Database Project (RDP) (R10, U27) database consisting of 1,519,356 bacterial 16S rRNA (http://mica.ibest .uidaho.edu/) (Shyu et al. 2007).

\section{Results and Discussion}

Small-scale traditional dadih manufacturing has been practiced in West Sumatra for many years and provides an additional income for herdsmen, particularly in rural areas. Two different fermentation techniques are currently practiced: the spontaneous method and the back-slopping method. In spontaneous fermentation, bamboo tubes are filled with fresh buffalo milk and covered with banana leaves or plastic and incubated at room temperature for 48 $\mathrm{h}$ (Surono 2003). In contrast, the back-slopping method involves adding a small amount of already fermented dadih to the fresh buffalo milk before incubation.

Huge diversity of microorganisms, particularly LAB, has been identified in association with dadih fermentation (Surono 2003; Mustopa and Fatimah 2014; Syukur et al. 2014; Wirawati et al. 2019). Product quality and safety are linked to the diversity and population of microorganisms contained in the raw materials used. Furthermore, both fermentation techniques tend to promote changes in LAB diversity, due to the intrinsic ability of these organisms to grow synergistically and interact with one another.

\subsection{Microbiological and $\mathrm{pH}$ analysis}

Microbial analysis (total LAB) and the $\mathrm{pH}$ of dadih samples are shown in Figures 1 and 2.

Figure 1 shows an increase in the total number of viable LAB colonies grown on the plates at $24 \mathrm{~h}$, followed by a slow decline over the following next $24 \mathrm{~h}$. This pattern was observed in both fermentation methods (Figure 1) and also correlates with reduction in $\mathrm{pH}$ (Figure 2). Furthermore, the reduced LAB cell numbers recorded at the end of fermentation occurred synergistically with the decline in $\mathrm{pH}$, with post-process acid production being identified as the main causative factor (Wang et al. 2002).

The change in acidity reported was related to the

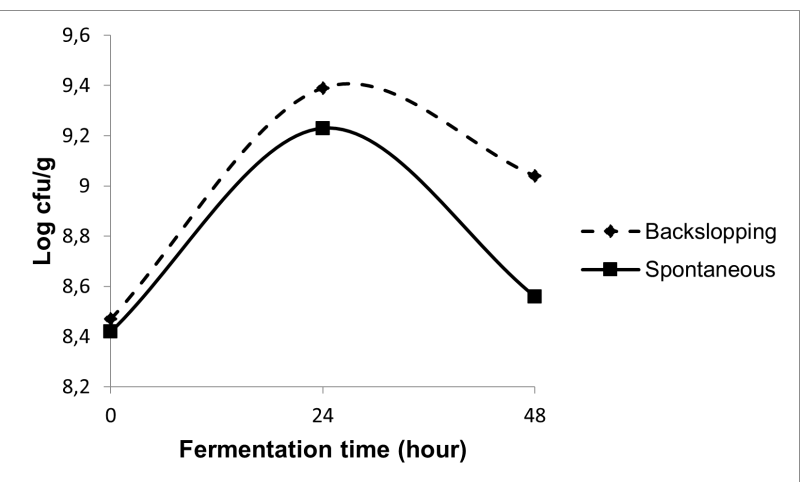

FIGURE 1 Changes in total viable LAB during dadih manufacturing by spontaneous and back-slopping methods. The dotted line indicates the back-slopping method while the continuous line indicates the spontaneous method. metabolic activity of lactic microbiota, characterized by their ability to hydrolyse fermentable sugars and milk proteins (de Oliveira 2014). The metabolic activities in which LAB are involved in the manufacture of fermented foods and the development of their flavour are (a) glycolysis (fermentation of sugars), (b) lipolysis (degradation of fat) and (c) proteolysis (degradation of proteins) (Bintsis 2018). The most important feature during milk fermentation is rapid acidification resulting from organic-acid formation, including lactic and acetic acids. These LAB metabolites, bacteriocins and some low-molecular-weight compounds are known to demonstrate antimicrobial activities, with the propensity to contribute to decreasing the number of viable cells (Chakoosari et al. 2014).

\subsection{Lactic acid bacteria (LAB) profile in dadih fermen- tation}

This study was performed using the T-RFLP method to profile the dynamic diversity of LAB during dadih production. The DNA metagenome from each fermentation period was used as the template for 16S rRNA gene amplification, with a pair of forward and reverse primers ( $7 \mathrm{f}$ forward primer labelled with FAM and specific reverse primer for LAB SG-Lab-0677) applied to amplify the region target at this stage (Figure 3).

These materials were successfully able to detect the diversity of LAB communities in the ecosystem (Baniyah et al. 2018). The $16 \mathrm{~S}$ rRNA amplification fragment was cut by two individual restriction enzymes (HaeIII and DdeI). However only HaeIII delivered a clear pattern in agarosa gel (Figure 4) and in an electropherogram (data not shown). In addition, the fragment (TRF) length of HaeIII generated ranged from $68 \mathrm{bp}$ to $331 \mathrm{bp}$ (Figure 4).

The HaeIII enzyme was able to distinguish all metagenome DNA samples, as different band patterns were demonstrated in agarose gel. Previous studies have also provided similar outcomes with various populations (Mulyawati et al. 2019).

Overall, the back-slopping and spontaneous methods contain 10 and 9 TRFs LAB phylotypes, respectively, after

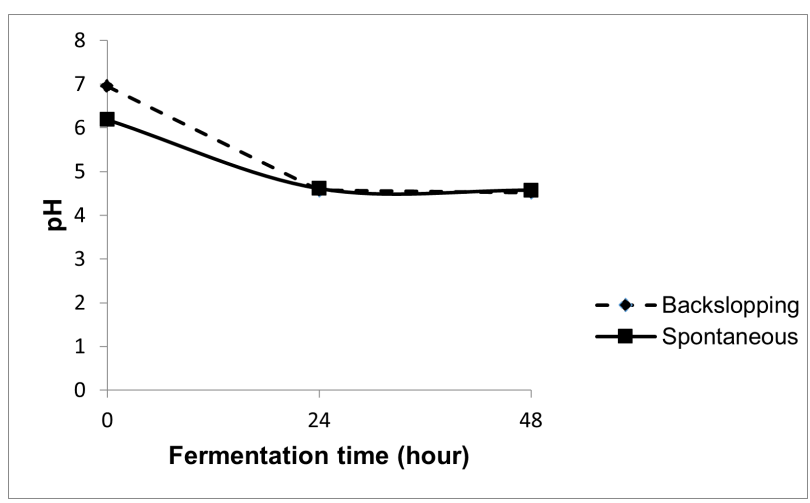

FIGURE 2 Changes in $\mathrm{pH}$ during dadih manufacturing by spontaneous and back-slopping methods. The dotted line indicates the back-slopping method while the black line indicates the spontaneous method. 


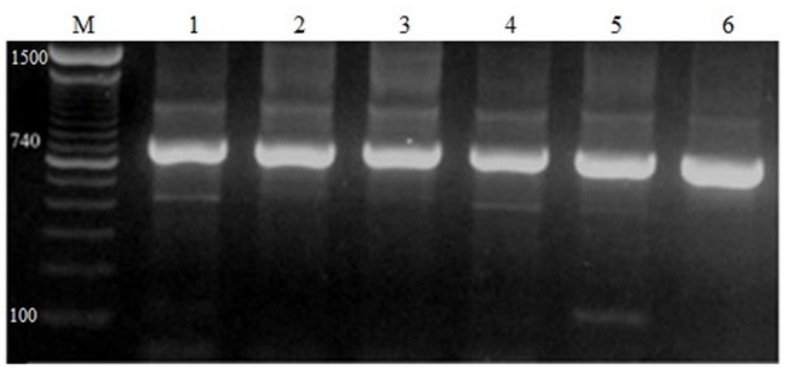

FIGURE 3 PCR product of LAB 16 S rRNA genes in 1\% agarosa gel. Lines 1 and 4: fresh buffalo milk from Kamang and Gadut; lines 2 and 3: back-slopping fermented dadih at 24 and $48 \mathrm{~h}$ fermentation; lines 5 and 6; spontaneous fermented dadih at 24 and $48 \mathrm{~h}$ fermentation.

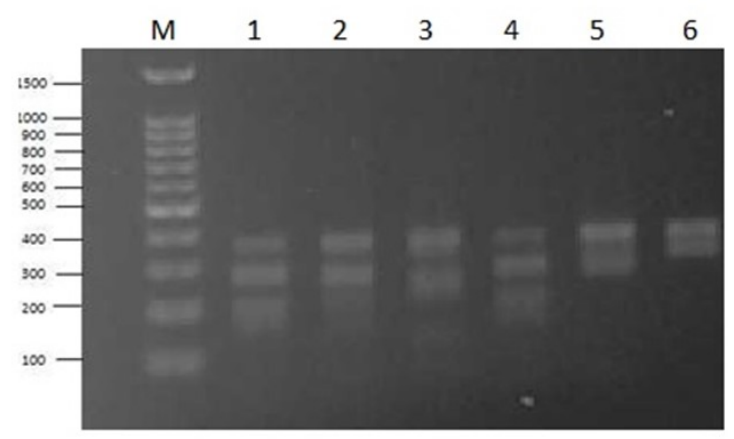

FIGURE 4 RFLP pattern from restriction digestion with individual restriction enzyme Haelll.

restriction at all stages of the fermentation process. However, two TRFs reported in both include those with 68 and 310 bp in which 8 and 7 specific phylotypes were identified, respectively. The addition of previously prepared dadih to fresh buffalo milk was assumed to have triggered the fermentation process, as similar TRF numbers were reported. Furthermore, the number of indigenous microflora also increased, as the introduced sample contained a stable LAB consortia. This was directly related to the carryover of microorganisms from the back-slopping process, with LAB being the predominant microorganisms identified (Moran et al. 2006). A study by (Kim et al. 2018) showed a constant number of total LAB in kefir produced through back-slopping, as compared with the traditional method. The result also showed that scaled-up production with good yield being attainable alongside improved sensory properties and prolonged shelf-life. This finding was also correlated with the total LAB colonies grown on plates, as the dadih output had higher total LAB $\left(9.5 \times 10^{9}\right.$ $\mathrm{cfu} / \mathrm{g})$ compared to the yield from the spontaneous method $\left(9.3 \times 10^{9} \mathrm{cfu} / \mathrm{g}\right)$. Similar results have been observed in the fermented foods kivunde (made from cassava) and ogi (made from corn) (Kimaryo et al. 2000; Teniola et al. 2005).

The presence of TRF amplifications at $68 \mathrm{bp}$ and 310 bp after treatment with the two methods indicates

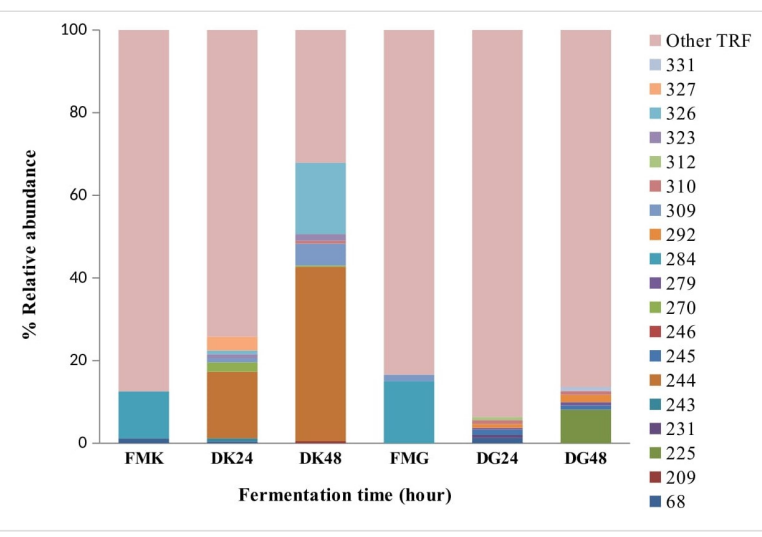

FIGURE 5 TRF distribution and relative abundance during the fermentation process. FMK: fresh buffalo milk from Kamang; FMG: fresh buffalo milk from Gadut; DK: dadih from Kamang; DG: dadih from Gadut; 24, 48: fermentation time (h).

that both are common phylotypes in fermented milk. In in-silico analysis, these TRFs were identified as Lactobacillus fermentum, Fructobacillus pseudoficulneus, Leuconostoc citreum, Leuconostoc kimchii, and Leuconostoc sp. Previous studies have positively identified these species in various fermented-milk products (Yu et al. 2011; Ao et al. 2012; Zafar et al. 2018). Generally, the expected microflora is dominated either by the Lactobacillales group or the Enterobacteriaceae group, depending on the incubation temperature or the milk source (Fugl et al. 2017). In addition, 284 TRF, usually identified as Lactobacillus renini, Lactobacillus brevis and Lactobacillus $s p$., were the common phylotypes in fresh buffalo milk often involved in cheese production, while others varied between regions (Uroić et al. 2016).

Figure 5 shows a high TRF number (8 and 7) and abundance in dadih fermented through back-slopping method (dadih from Kamang, DK 24 and DK48), compared to dadih from Gadut (DG24 and DG48) (7 and 5). Despite the similarity in TRF numbers of fresh buffalo milk, the relative abundance in fresh buffalo milk from Gadut (FMG) was slightly greater than in fresh buffalo milk from Kamang (FMK).

Each fermentation method is characterized by fluctuations in dynamic change among the first (0-24 h) and second periods (24-48 h) of fermentation. Figure 5 shows an increase to 8 TRFs during the first period of back-slopping, followed by decline to 7 . This deterioration was assumed to have resulted from nutrient limitation, metabolite accumulation and oxygen exposure causing cell death, as supported by Hayek and Ibrahim (2013). Furthermore, a similar phenomenon also occurred during the spontaneous fermentation process, featuring a decline from 7 to 5 TRFs, despite the higher relative abundance recorded in the second period.

The identification of TRFs was conducted using TRFLP ISPAR from the MiCA III RDP (R10, U27) database, comprising 1,519,356 bacterial 16S rRNA (Shyu et al. 2007). Table 1 shows the outcome from in-silico 
TABLE 1 In-silico identification of LAB TRF during fermentation process.

\begin{tabular}{|c|c|c|c|c|c|c|c|}
\hline \multirow{2}{*}{ TRF } & \multicolumn{3}{|c|}{ Backslopping method } & \multicolumn{3}{|c|}{ Spontaneous method } & \multirow{2}{*}{ - In silico identification } \\
\hline & 0 & 24 & 48 & 0 & 24 & 48 & \\
\hline 68 & $\sqrt{ }$ & $\sqrt{ }$ & & & $\sqrt{ }$ & & Lactobacillus fermentum \\
\hline 209 & & & $\sqrt{ }$ & & & & Lactobacillus sp. \\
\hline 225 & & & & & & $\sqrt{ }$ & $\begin{array}{l}\text { Lactobacillus coryneformis; Lactobacillus bifermentans; Lactobacillus satsi- } \\
\text { mensis }\end{array}$ \\
\hline 231 & & & & & $\sqrt{ }$ & & Aerococcus urinae \\
\hline 243 & & $\sqrt{ }$ & & & & & Lactobacillus fermentum \\
\hline 244 & & $\sqrt{ }$ & $\sqrt{ }$ & & $\sqrt{ }$ & & Lactobacillus amylovorus; Lactobacillus helveticus \\
\hline 245 & & & $\sqrt{ }$ & & $\sqrt{ }$ & $\sqrt{ }$ & Lactobacillus acidophilus \\
\hline 246 & & & & & & $\sqrt{ }$ & $\begin{array}{l}\text { Lactobacillus helveticus; uncultured Lactobacillus sp.; Lactobacillus gali- } \\
\text { narum; Lactobacillus amylovorus; Lactobacillus crispatus }\end{array}$ \\
\hline 270 & & $\sqrt{ }$ & $\sqrt{ }$ & & & & Leuconostoc gelidium \\
\hline 279 & & & & & $\sqrt{ }$ & $\sqrt{ }$ & $\begin{array}{l}\text { Uncultured Lactobacillus sp.; Lactobacillus agilis; Lactobacillus delbrueckii } \\
\text { subsp. delbrueckii; Lactobacillus delbrueckii subsp. lactis; Lactobacillus sali- } \\
\text { varus; Lactobacillus delbrueckii subsp. bulgaricus; Lactobacillus delbrueckii } \\
\text { subsp. indicus }\end{array}$ \\
\hline 284 & $\sqrt{ }$ & & & $\sqrt{ }$ & & & Lactobacillus renini; Lactobacillus brevis; Lactobacillus sp., \\
\hline 292 & & & & & $\sqrt{ }$ & $\sqrt{ }$ & $\begin{array}{l}\text { Lactobacillus sunkii; Lactobacillus otakiensis; Lactobacillus brucneri; Lacto- } \\
\text { bacillus parabuchneri; Lactobacillus fermentum }\end{array}$ \\
\hline 309 & & & $\sqrt{ }$ & $\sqrt{ }$ & & & Uncultured Streptococcus sp. \\
\hline 310 & & & $\sqrt{ }$ & & & $\sqrt{ }$ & $\begin{array}{l}\text { Fruktobacillus pseudoficulneus; Leuconostoc citreum; Leuconostoc kimchii; } \\
\text { Leuconostoc sp. }\end{array}$ \\
\hline 312 & & & & & $\sqrt{ }$ & & Leuconostoc citreum; uncultured bacterium \\
\hline 323 & & $\sqrt{ }$ & $\sqrt{ }$ & & & & Lactobacillus intermedium \\
\hline 326 & & $\sqrt{ }$ & $\sqrt{ }$ & & & & $\begin{array}{l}\text { Lactobacillus farcimis; Lactobacillus alimentarius; Lactobacillus paralimen- } \\
\text { taius; Lactobacillus casei; Lactobacillus bobalius; Lactobacillus pentosus; Lac- } \\
\text { tobacillus plantarum; Lactobacillus crustosus }\end{array}$ \\
\hline 327 & & $\sqrt{ }$ & & & & & $\begin{array}{l}\text { Lactobacillus manihotivorans; Lactobacillus plantarum; Lactobacillus pen- } \\
\text { tosus; Lactobacillus nantensis; Lactobacillus paralimentarius; Lactobacillus } \\
\text { crustosus; Lactobacillus malefermentans; Lactobacillus similis; Lactobacillus } \\
\text { plantarum subsp. plantarum; Lactobacillus sp. }\end{array}$ \\
\hline 331 & & & $\sqrt{ }$ & & & $\sqrt{ }$ & $\begin{array}{l}\text { Lactobacillus pantheris; Lactobacillus curvatus; Lactobacillus lactis; uncul- } \\
\text { tured Lactobacillus sp.; Lactococcus lactis }\end{array}$ \\
\hline
\end{tabular}

determination, featuring the inability to classify all, with approximately $42.5 \%$ unidentified TRFs referred to the MiCA III database while several others (32.9\%) were categorized as uncultured bacteria. Conversely, one was ascertained as being more than one species, with TRF 244 identified as L. helveticus or L. amylovorus.

Table 1 shows a fluctuation in the TRFs present through the duration of both fermentation processes (24 and $48 \mathrm{~h}$ ). Also, the method adopted affected the specific LAB phylotype present, as 244 bp TRF, similar to L. helveticus and L. amylovorus, was limited to the backslopping sample, while $278 \mathrm{bp}$, analogous to L. delbrueckii ssp. lactis, L. delbrueckii ssp. bulgaricus, L. delbrueckii ssp. delbrueckii, L. delbrueckii ssp. indicus and L. agilis, was only recognized in the spontaneous method. In addition, some LAB phylotypes were common to both manufacturing processes, while others were specific to one or the other.

A study conducted by Venema and Surono (2019) using a more advance method (next generation sequencing or NGS) showed more comprehensive results for dadih mi- crobiota profiles other than LAB. Interestingly, their study recommended the back-slopping method as suppressing pathogenic bacteria resulting from unhygienic conditions in dadih processing. This result is in line with our finding that the higher LAB phylotype richness in the backslopping method corresponded to better safety and quality. We also found that although the NGS method provides a cost-effective alternative that can provide a higher level of information for individual members of the microbial population, the T-RFLP method is still a relevant tool for studying the microbial community in dadih ecosystems.

\section{Conclusions}

This study involved the use of the T-RFLP method of tagged 16S rRNA gene amplicons to generate an overview of LAB populations during dadih manufacturing through back-slopping and spontaneous fermentation methods. Diverse specific LAB phylotypes were identified, with total $\mathrm{LAB}$, phylotype richness and relative abundance were higher in the back-slopping technique. Two common 
TRFs, at 68 and $310 \mathrm{bp}$, were recorded in both fermentation methods. The T-RFLP method detected some phylotypes, comprising a total of 18 identified LAB (24.7\%) and 24 uncultured LAB (32.9\%), with the remaining 42.5\% being unidentified. A deficiency in existing databases has produced problems related to the generation of comprehensive investigations of bacterial consortia diversity. The findings of this research are expected to be useful in comparing the two dadih fermentation methods, thus providing scientific reasons for possible adjustments to the procedures used in rural communities. Of the options studied, 24 hour fermentation with the back-slopping method is recommended, as a longer fermentation time significantly reduced viable $\mathrm{LAB}$.

\section{Acknowledgments}

This study was support by a BUDI-DN (Beasiswa Unggulan Dosen Indonesia Dalam Negeri) scholarship from LPDP (Lembaga Pengelola Dana Pendidikan), Ministry of Finance, Republic of Indonesia.

\section{Authors' contributions}

BJ, WM, DA, AB designed the study. BJ, WM, DA, MS carried out the laboratory work. BJ, WM, DA, AB, MS, $\mathrm{IB}, \mathrm{HM}, \mathrm{KY}$, BS analyzed the data. BJ, WM wrote the manuscript. All authors read and approved the final version of the manuscript.

\section{Competing interests}

The author declare that they have no competing interest.

\section{References}

Ao X, Zhang X, Zhang X, Shi L, Zhao K, Yu J, Dong L, Cao Y, Cai Y. 2012. Identification of lactic acid bacteria in traditional fermented yak milk and evaluation of their application in fermented milk products. J Dairy Sci. 95(3):1073-1084. doi:10.3168/jds.2011-4224.

Baniyah L, Nur Jannah S, Rukmi I, Sugiharto. 2018. Molecular diversity of lactic acid bacteria on ileum broiler chicken fed by bran and bran fermentation. J Phys Conf Ser. 1025(1). doi:10.1088/17426596/1025/1/012049.

Bintsis T. 2018. Lactic acid bacteria as starter cultures: An update in their metabolism and genetics. AIMS Microbiol. 4(4):665-684. doi:10.3934/microbiol.2018.4.665.

Chakoosari MMD, Ghasemi MF, Masiha A. 2014. Antimicrobial Activities of Lactic Acid Bacteria. Bull Environ Pharmacol Life Sci. 3(2):275-278.

de Oliveira MN. 2014. Fermented Milks: Fermented Milks and Yogurt. In: Encyclopedia of Food Microbiology: Second Edition. p. 908-922. doi:10.1016/B978-0-12-384730-0.00121-X.
Dervisoglu M, Aydemir O. 2007. Physicochemical and microbiological characteristics of Kulek cheese made from raw and heat-treated milk. World J Microbiol Biotechnol. 23(4):451-460. doi:10.1007/s11274006-9246-x.

Efriwati, Suwanto A, Rahayu G, Nuraida L. 2013. Population Dynamics of Yeasts and Lactic Acid Bacteria (LAB) During Tempeh Production. HAYATI J Biosci. 20(2):57-64. doi:10.4308/hjb.20.2.57.

Ercolini D. 2013. High-Throughput Sequencing and Metagenomics: Moving Forward in the CultureIndependent Analysis of Food Microbial Ecology. Appl Environ Microbiol. 79(10):3148-3155. doi:10.1128/aem.00256-13.

Fugl A, Berhe T, Kiran A, Hussain S, Laursen MF, Bahl MI, Hailu Y, Sørensen KI, Guya ME, Ipsen R, Hansen EB. 2017. Characterisation of lactic acid bacteria in spontaneously fermented camel milk and selection of strains for fermentation of camel milk. International Dairy Journal 73:19-24. doi:10.1016/j.idairyj.2017.04.007.

Hayek SA, Ibrahim SA. 2013. Current Limitations and Challenges with Lactic Acid Bacteria: A Review. Food Nutr Sci. 04(11):73-87. doi:10.4236/fns.2013.411a010.

Jannah SN, Dinoto A, Wiryawan KG, Rusmana I. 2016. Molecular diversity pattern of intestinal lactic acid bacteria in Cemani chicken, Indonesian native chicken, as revealed by terminal restriction fragment length polymorphisms. Malays J Microbiol. 12(1):102-111. doi:10.21161/mjm.73815.

Jernberg C, Sullivan Å, Edlund C, Jansson JK. 2005. Monitoring of antibiotic-induced alterations in the human intestinal microflora and detection of probiotic strains by use of terminal restriction fragment length polymorphism. Appl Environ Microbiol. 71(1):501-506. doi:10.1128/AEM.71.1.501-506.2005.

Kim DH, Jeong D, Song KY, Seo KH. 2018. Comparison of traditional and backslopping methods for kefir fermentation based on physicochemical and microbiological characteristics. Lwt. 97:503-507. doi:10.1016/j.lwt.2018.07.023.

Kimaryo VM, Massawe GA, Olasupo NA, Holzapfel WH. 2000. The use of a starter culture in the fermentation of cassava for the production of 'kivunde', a traditional Tanzanian food product. International Journal of Food Microbiology 56(2-3):179190. doi:10.1016/S0168-1605(00)00159-8.

Lackey KA, Williams JE, Price WJ, Carrothers JM, Brooker SL, Shafii B, McGuire MA, McGuire MK. 2017. Comparison of commercially-available preservatives for maintaining the integrity of bacterial DNA in human milk. J Microbiol Methods. 141:73-81. doi:10.1016/j.mimet.2017.08.002.

Moran CA, Scholten RHJ, Tricarico JM, Brooks PH, Verstegen MWA. 2006. Fermentation of wheat: Effects of backslopping different proportions of prefermented wheat on the microbialand chemical com- 
position. Archives of Animal Nutrition 60(2):158169. doi:10.1080/17450390600562700.

Mulyawati AI, Jatmiko YD, Mustafa I, Ardyati T, Suharjono. 2019. Diversity of lactic acid bacteria isolated from fermented mare's milk products based on PCRRFLP analysis. P Conf Ser Earth Environ Sci. 230(1). doi:10.1088/1755-1315/230/1/012104.

Mustopa AZ, Fatimah F. 2014. Diversity of Lactic Acid Bacteria Isolated from Indonesian Traditional Fermented Foods. Microbiol Indones. 8(2):48-57. doi:10.5454/mi.8.2.2.

Nduko JM, Matofari JW, Nandi ZO, Sichangi MB. 2017. Spontaneously fermented kenyan milk products: A review of the current state and future perspectives. African J Food Sci. 11(1):1-11. doi:10.5897/ajfs2016.1516.

Prakash O, Pandey PK, Kulkarni GJ, Mahale KN, Shouche YS. 2014. Technicalities and Glitches of Terminal Restriction Fragment Length Polymorphism (T-RFLP). Indian J Microbiol. 54(3):255-261. doi:10.1007/s12088-014-0461-0.

Rademaker JL, Peinhopf M, Rijnen L, Bockelmann W, Noordman WH. 2005. The surface microflora dynamics of bacterial smear-ripened Tilsit cheese determined by T-RFLP DNA population fingerprint analysis. Int Dairy J. 15(6-9):785-794. doi:10.1016/j.idairyj.2004.08.027.

Schütte UM, Abdo Z, Bent SJ, Shyu C, Williams CJ, Pierson JD, Forney LJ. 2008. Advances in the use of terminal restriction fragment length polymorphism (TRFLP) analysis of 16S rRNA genes to characterize microbial communities. Appl Microbiol Biotechnol. 80(3):365-380. doi:10.1007/s00253-008-1565-4.

Shyu C, Soule T, Bent SJ, Foster JA, Forney LJ. 2007. MiCA: A web-based tool for the analysis of microbial communities based on terminal-restriction fragment length polymorphisms of $16 \mathrm{~S}$ and 18S rRNA genes. Microb Ecol. 53(4):562-570. doi:10.1007/s00248006-9106-0.

Surono IS. 2003. In vitro probiotic properties of indigenous dadih lactic acid bacteria. Asian-Australas J Anim Sci. 16(5):726-731. doi:10.5713/ajas.2003.726.

Syukur S, Rijal F, Jamsari, Purwati E. 2014. Isolation and molecular characterization of lactic acid bacteria by using 16s rRNA from fermented buffalo milk (Dadih) in Sijunjung, West Sumatera. Res J Pharm, Biol Chem Sci. 5(6):871-876.

Teniola OD, Holzapfel WH, Odunfa SA. 2005. Comparative assessment of fermentation techniques useful in the processing of ogi. World J Microbiol Biotechnol. 21(1):39-43. doi:10.1007/s11274-004-1549-1.

Uroić K, Novak J, Hynönen U, Pietilä TE, Leboš Pavunc A, Kant R, Kos B, Palva A, Šušković J. 2016. The role of S-layer in adhesive and immunomodulating properties of probiotic starter culture Lactobacillus brevis D6 isolated from artisanal smoked fresh cheese. LWT - Food Sci Technol. 69:623-632. doi:10.1016/j.lwt.2016.02.013.

Venema K, Surono IS. 2019. Microbiota composition of dadih - a traditional fermented buffalo milk of West Sumatra. Letters in Applied Microbiology 68(3):234240. doi:10.1111/lam.13107.

Wanangkarn A, Liu DC, Swetwiwathana A, Jindaprasert A, Phraephaisarn C, Chumnqoen W, Tan FJ. 2014. Lactic acid bacterial population dynamics during fermentation and storage of Thai fermented sausage according to restriction fragment length polymorphism analysis. Int J Food Microbiol. 186:61-67. doi:10.1016/j.ijfoodmicro.2014.06.015.

Wang YC, Yu RC, Chou CC. 2002. Growth and survival of bifidobacteria and lactic acid bacteria during the fermentation and storage of cultured soymilk drinks. Food Microbiol. 19(5):501-508. doi:10.1006/fmic.2002.0506.

Wirawati CU, Sudarwanto MB, Lukman DW, Wientarsih I, Srihanto EA. 2019. Diversity of lactic acid bacteria in dadih produced by either back-slopping or spontaneous fermentation from two different regions of West Sumatra, Indonesia. Vet World. 12(6):823-829. doi:10.14202/vetworld.2019.823-829.

Yu J, Wang WH, Menghe BL, Jiri MT, Wang HM, Liu WJ, Bao QH, Lu Q, Zhang JC, Wang F, Xu HY, Sun TS, Zhang HP. 2011. Diversity of lactic acid bacteria associated with traditional fermented dairy products in Mongolia. J Dairy Sci. 94(7):3229-3241. doi:10.3168/jds.2010-3727.

Zafar SB, Siddiqui NN, Shahid F, Qader SAU, Aman A. 2018. Bioprospecting of indigenous resources for the exploration of exopolysaccharide producing lactic acid bacteria. J Genet Eng Biotechnol. 16(1):17-22. doi:10.1016/j.jgeb.2017.10.015.

Zhang J, Wang X, Huo D, Li W, Hu Q, Xu C, Liu S, Li C. 2016. Metagenomic approach reveals microbial diversity and predictive microbial metabolic pathways in Yucha, a traditional Li fermented food. Sci Rep. 6. doi:10.1038/srep32524. 